\title{
Local Ecological Knowledge on Food Materials of Land Plant Origin in Kabola Ethnic Communities in Alor District, East Nusa Tengara Province
}

\author{
Sanherip Laalobang1, I. W. Mudita², dan Yosep Seran Mau²
}

${ }^{1}$ Environmental Science Student at the Postgraduate Program at the University of Nusa Cendana Kupang; e-mail: laalobong@yahoo.co.id

${ }^{2}$ Lecturer at the Postgraduate Program at the University of Nusa Cendana Kupang

\begin{abstract}
Local Ecological Knowledge (LEK) regarding local food plants is knowledge that is owned by local communities and is passed down from generation to generation. LED is obtained through a long process of adaptation and is used by local communities to address environmental problems. The Kabola ethnic group also has LEK regarding food plants used to solve food problems on dry land, but the LEK owned by the Kabola ethnic community is in danger of being lost. The method used is a mixed method (Mixed Methodology), which combines qualitative methods and quantitative methods, data collection begins with an exploration using a qualitative case study method by means of in-depth interviews followed by a quantitative survey method of the plant species mentioned during the interview. The results showed that the Kabola ethnic group still collects wild food plants from forests, former gardens and riverbanks, even though they have cultivated various types of food crops; The Kabola ethnic group community collects food plants during the rainy season and dry season, but most food gathering activities are carried out at the end of the rainy season and during the dry season; The people of the Kabola ethnic group collect food by using simple tools while leaving certain parts of the plant from which the food is collected; The people of the Kabola ethnic group still pass on local knowledge about foodstuffs to the younger generation through stories, personal experiences and providing examples or direct practices about plants that can be used to meet food needs; The Kabola ethnic group cultivates local food plants, but these cultivation efforts are only carried out individually and have not received support from the local government.
\end{abstract}

Keywords: Local Ecological Knowledge (PEL), Ethnic Kabola, Alor District, Food Plants, Local Food

Citation: Laalobang, S., Mudita, I.W., dan Mau, Y.S. (2021). Local Ecological Knowledge on Food Materials of Land Plant Origin in Kabola Ethnic Communities in Alor District, East Nusa Tengara Province. Jurnal Ilmu Lingkungan, 19(1), 43-52, doi:10.14710/jil.19.1.43-52

\section{Introduction}

Local Ecological Knowledge (LEK) is a new approach to understanding the relationship between local communities and their environment. LEK is a management system that is used interchangeably with other resource management systems and such systems may be based on elements adapted from traditional systems (Berkes and folke 1994). According to Inglis et al. (1993), LEK represents the experiences local communities have gained over thousands of years through direct contact with the environment. Furthermore, according to Berkes (2000) LEK is a collection of knowledge, practices, and cumulative beliefs, which develop through a process of adaptation and are passed on from generation to generation through cultural transmission, regarding the relationship of living things (including humans) with other living things and with their environment. The relationship between local communities and the environment and available natural resources gradually forms certain behaviors and habits or procedures as a way to adapt (Hapsari, 2013).
Adaptation is a process that is not easy and takes a long time. According to Williams (1996) adaptation for a long time is needed for the sustainability of a population so that the population is unlikely to become extinct. Adaptation over a long period of time produces a separate knowledge for the local community. LEK, together with traditional ecological knowledge (TEK), develops through a process of cultural adaptation to the environment so that humans can use resources sustainably to ensure their long-term survival in certain locations (Charnley et al., 2007). The relationship between local communities and their environment is reflected in the use of existing natural resources to meet their daily needs. Torre-Cuadro \& Islebe (2003) found the use of nonwood products such as edible fruit, oil, latex, and fiber to meet the needs of life. Albuquerque (2017) suggests that tribal communities in Brazil use plants for food, shelter, or clothing.

LEK regarding local food ingredients is closely related to LEK regarding medicinal plants because many medicinal plant species can also be food- 
Laalobang, S., Mudita, I.W., dan Mau, Y.S. (2021). Local Ecological Knowledge on Food Materials of Land Plant Origin in Kabola Ethnic Communities in Alor District, East Nusa Tengara Province. Jurnal IImu Lingkungan, 19(1), 43-52, doi:10.14710/jil.19.1.43-52

producing plants so that food diversity, apart from nutrition, is also medicinal (Fadhilah, 2013). Malnutrition experienced by dry land communities occurs not only because of a lack of food, but also because of a lack of knowledge about alternative food available in their environment. According to Frankenberger et al., (2012), local communities and customary institutions can take advantage of LEK to overcome climate variability, conflict, and food shortages. LEK regarding local food can become the basis for developing policies on the use of food resources for dry land communities and their preservation (Menzies 2006). In addition, LED can also be used to assist the process of biodiversity conservation, especially the conservation of local food-producing plants because local ethnic groups always protect their natural resources (Berkes et al., 1995). According to Toledo \& Burlingame (2006), the efforts given by local communities and indigenous peoples regarding biodiversity in local and traditional food systems in carrying out conservation and sustainable management of local food biodiversity, can provide foodstuffs to dry land communities in the mountains and ecosystems. other dry land.

Although LEK regarding local food is very important, according to previous researches, LEK regarding local food is threatened with disappearing due to various factors such as what Purwaningsih (2008) stated; Martianto et al (2009a) stated that local food is in danger of being lost due to lack of attention from the government. Changes in local culture to modern culture are always balanced with changes in knowledge and consumption patterns of local communities (Elfitri et al., 2017). The community's habit of applying the manoculture system resulted in the loss of local varieties of plants (Dickinson, 1972). According to Swaminathan (2016), the introduction of superior varieties of food plants is the factor that most threatens the sustainability of local food plants.

Indonesia has very many local community groups. BPS data (2010) states that Indonesia has 1340 ethnic groups or ethnic groups, including the Kabola ethnic group in Alor Regency, NTT Province. Based on the research results of Fauzi et al. (2017), the Kabola ethnic group community has a high LEK regarding medicinal plants so that it can be assumed that they also have a high LEK regarding local food ingredients. The majority of ethnic Kabola in Alor Regency make a living as dry land farmers. According to data from the BPS of Alor Regency (2018), the area of dry agricultural land that has been cultivated by the community in Kabola sub-district is 7,301 ha. Apart from farming, the Kabola ethnic community is still very strong dependent on hunting and gathering activities so that he is suspected of having adequate knowledge of local food. The purpose of this study was to determine the threat to the sustainability of local food plants in the Kabola ethnic group in Kabola District, Alor Regency, East Nusa Tenggara Province.

\section{Research Methodology}

\subsection{Location and Time of Research}

The research was conducted in Kabola District, Alor Regency, East Nusa Tenggara Province in 2019. Kabola District was chosen as the research location because it is the residence of the Kabola ethnic group. The map of the research location is shown in Figure 1.

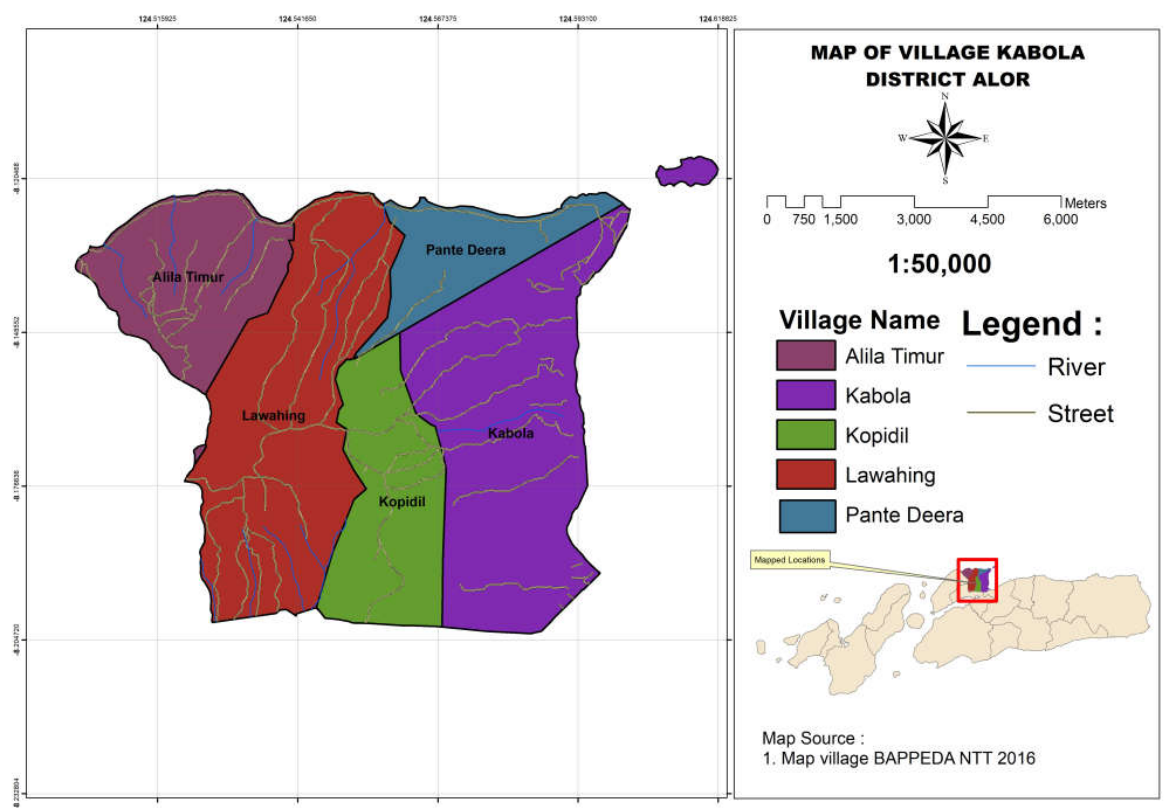

Figure 1. Map of Kabola Sub-District Which is Used as a Research Location

\subsection{Research Methodology}

Research has been conducted using a mixed methodology by combining qualitative methods and quantitative methods sequentially (exploratory sequential mixed method design) (Creswell, 2014).
Data collection begins with an exploratory manner using a qualitative case study method by conducting in-depth interviews with a number of informants (Creswell, 2007). Then the data collection was continued by using a quantitative survey method of 
the types of plants mentioned by the interviewees. The two surveys were conducted to confirm the taxonomic identity of plant species used as food ingredients mentioned in in-depth interviews (Reátegui et al., 2018; Francesconi et al. 2018; (Nunes et al. 2018).

\subsection{Sources and Types of Data}

The data collected consists of primary data and secondary data as follows:

1. Primary data, is data that is collected directly through in-depth interviews or through field observation surveys. Primary data collected consisted of: Local Ecological Knowledge of the Kabola ethnic community accompanied by: 1) description of wild plant and animal samples used as local food, (2) location and description of collection locations, and (3) description of the use and processing that need to be done before utilization.

2. Secondary data, is data collected from related agencies such as BPS (population data), BMKG (rainfall and temperature data), Village/subdistrict offices (village/sub-district potential data), and other sources, including data from sources. -source online (online). The secondary data collected will be used to complement the primary data.

\subsection{Sampling}

The sample in this study consisted of samples of in-depth interview sources, samples of plants used as local foodstuffs, and samples of observations of the use and processing of food plants. Samples for the three methods of data collection were each taken separately.

Samples for in-depth interview interviewees were determined by using stratified purposive sampling method. For this purpose, the community in each village / kelurahan in the research location should first be divided into the following strata: (1) customary leaders, (2) community leaders, and (3) farming communities, hunters and gatherers.

Samples for field observations of terrestrial food plants consist of locations where the community in each village / kelurahan usually cultivates or collects plants for foodstuffs. In each village / kelurahan, two locations are determined purposively with the following criteria:

1. The location of cultivation, where the community is farming with the types of plants mentioned in the in-depth interview, is made observations starting from the highest point to the lowest point in that location accompanied by taking geographic coordinates of the points where food plants are found.

2. The location of abandoned forest or shrubs excultivation, in the same way as in the cultivation location, but accompanied by taking the coordinate points where the community obtained the food plants mentioned in the in-depth interview.

Observation of the characteristics and location of food plants is carried out using descriptive techniques equipped with photos, with participatory mapping techniques (also called community-based mapping, community mapping) with the support of the Earth GIS online mapping application installed on a laptop computer and connected to the internet using a mobile phone filled with data packages.

Samples for observing the use and processing of food plant species were determined purposively. Indepth interviews were conducted with resource persons who were using and processing plant species as mentioned in the in-depth interviews. From each village / kelurahan, at least one sample is determined for each type of food plant which in the interview stated that it is used and processed in certain ways.

\subsection{Data Analysis}

Qualitative data were analyzed using thematic analysis techniques by identifying unique themes, linking one unique theme to another, determining patterns of association of these unique themes, organizing these unique themes into themes. general meaning, and interpret these general themes in the context of the research. In this case the theme represents something important in the data and shows a certain patterned or meaningful response in relation to the research question. Thematic analysis using the Microsof word application.

Quantitative data were analyzed using: (1) spatial analysis techniques for mapping the location of plant species (2) descriptive statistical analysis techniques to describe the knowledge of the community between villages/ sub-district in the research location.

\section{Result and Discussion}

\subsection{Physical Condition-Bilogy Environment Research Location}

Geographically, Kabola District is located in the northern part of Alor Regency, East Nusa Tenggara Province. According to the Regional Regulation (Perda) of Alor Regency Number 15 (2005), geographically Kabola District is bordered by the North with the Flores Sea, the East with Benlelang Bay, the South with Alor Tengah Utara District and Teluk Mutiara District, West with Alor Barat District Laut and Teluk Mutiara District.

The area of Kabola District is 73,01 $\mathrm{km}^{2}$, consisting of four villages and one sub-district, namely Pante Deere Village, East Alila Village, Kopidil Village, Lawahing Village and Kabola Village. Geographically, the areas of villages and sub-districts in Kabola District spread from the coastal area to the mountains, except for Kopidil Village which is only in the mountains, with an altitude of Kabola District ranging from 0 - $650 \mathrm{~m}$. Based on data from the Meteorology, Climatology, Geophysics Agency (BMKG), Alor Regency (2018), the average rainfall in Kabola District is $91,95 \mathrm{~mm}$. with the number of rainy days as much 
as 12, 99 days in a month. The average air temperature during $2014-2018$ was $27,16^{\circ} \mathrm{C}$ and the average humidity was $75,02 \%$.

Villages/wards in Kabola District have a slope in the range of $0-40 \%$. In accordance with the Regulation of the Minister of Agriculture Number 47/Permentan/OT.140/ 10 (2006), the slope of the Kabola District is categorized as flat, wavy, bumpy, hilly and mountainous. Kabola sub-district has two types of soil, namely eutric latosol soil (chromic latosol) and renzina soil. According to Subardja et al (2014), latosal soil has a high clay content ( $\geq 60 \%$ ), crumb to lumpy, loose and homogeneous, in deep soil sections with a diffuse horizon, and does not have a characteristic horizon unless buried more than $50 \mathrm{~cm}$. while renzina soil has an upper part mixed with clay ( $\geq 30 \%$ ), a fracture of at least $1 \mathrm{~cm}$, and if it is not affected by irrigation, then at a depth of $50 \mathrm{~cm}$ it will take the form of a roll and a kiln plane.

The largest use of agricultural land in Kabola District consists of fields / huma and the largest use of non-agricultural land is land that is temporarily not cultivated. In areas where cultivation is practiced, land that is not cultivated is an area of land that is being left fallow to restore soil fertility.

\subsection{Socio-Economic-Cultural Environment}

The population of Kabalo sub-district is spread across four villages and one kelurahan with different population densities, the details can be seen in table 1 .

Table 1. Total Population, Population Density, and Percentage of Population in Villages/ sub-district to Population of Kabola Subdistrict, Detailed for Each Village / Kelurahan in 2017

\begin{tabular}{lcccc}
\hline \hline Village/ sub-district & Total Population (person) & Area $\left(\mathrm{km}^{2}\right)$ & $\begin{array}{c}\text { Density Residents (people / km }{ }^{2} \text { ) } \\
\begin{array}{c}\text { \% Village / Subdistrict Population } \\
\text { Against Residents districts }\end{array}\end{array}$ & $\begin{array}{c}\text { (2,96 } \\
\text { Alila Timur }\end{array}$ \\
Kabola & 1.014 & 10,48 & 171 & 45,37 \\
Kopidil & 3.549 & 20,81 & 78 & 12,69 \\
Lawahing & 992 & 12,76 & 71 & 19,54 \\
Pante Deere & 1.529 & 21,28 & 96 & 9,44 \\
\hline Kabola District & 738 & $\mathbf{7 , 6 7}$ & $\mathbf{1 0 7}$ & $\mathbf{1 0 0 , 0 0}$ \\
\hline
\end{tabular}

Source: BPS Alor Regency (2018)

Table 1 shows the total population of Kabola Subdistrict, which amounted to 7.822 people in 2017, the most were in Kabola Village, namely 3.549 people, with a density of 171 people / $\mathrm{km} 2$, while the least was in Pante Deere Village, namely 738 people, with a density of 96 people. / $\mathrm{km}^{2}$. With a density of 171 people / $\mathrm{km}^{2}$, Kelurahan Kabola had the highest population density, while Desa Lawahin had the lowest population density, namely $71 / \mathrm{km}^{2}$. The total population of Kabola District based on gender can be seen in table 2.

Table 2 shows that the population of Kabola Subdistrict is more male with a sex ratio of 0,95 . The village / kelurahan with the highest gender ratio was Kabola Village, while the village / kelurahan with the lowest gender ratio was Alila Timur Village.

Table 2. Total Population by Sex and Sex Ratio of Population in Kabola District, Alor Regency, NTT Province

\begin{tabular}{lcrrr}
\hline \multicolumn{1}{c}{ Village/sub-district } & Male & Female & Total & Gender Ratio \\
\hline Alila Timur & 463 & 551 & 1.014 & 0,84 \\
Kabola & 1.768 & 1.781 & 3.549 & 0,99 \\
Kopidil & 489 & 503 & 992 & 0,97 \\
Lawahing & 747 & 782 & 1.529 & 0,96 \\
pantedaera & 346 & 392 & 738 & 0,88 \\
\hline Total Kabola District & $\mathbf{3 . 8 1 3}$ & $\mathbf{4 . 0 0 9}$ & $\mathbf{7 . 8 2 2}$ & $\mathbf{0 , 9 5}$ \\
\hline
\end{tabular}

Source: BPS Alor Regency (2018)

The education level of the residents of Kabola District varies from those who have not completed elementary school (SD) to the Masters level (S2). Details can be seen in Figure 1.

Graph 1 shows that the majority of the population in Kabola sub-district graduated from elementary school, namely $43,03 \%$ of the total population, followed by junior high school graduation, namely $19,04 \%$, and senior high school / vocational school, namely $11,95 \%$ of the total population. Kelurahan Kabola has the population with the most tertiary graduates, but also with the largest number of people who have only completed elementary school.

Lawahing Village has a population with the fewest college graduates, but also with the least number of residents who have not graduated from elementary school.
The livelihoods of the people of Kabola subdistrict vary, namely civil servant farmers, fishermen and traders, details can be seen in table 3 .

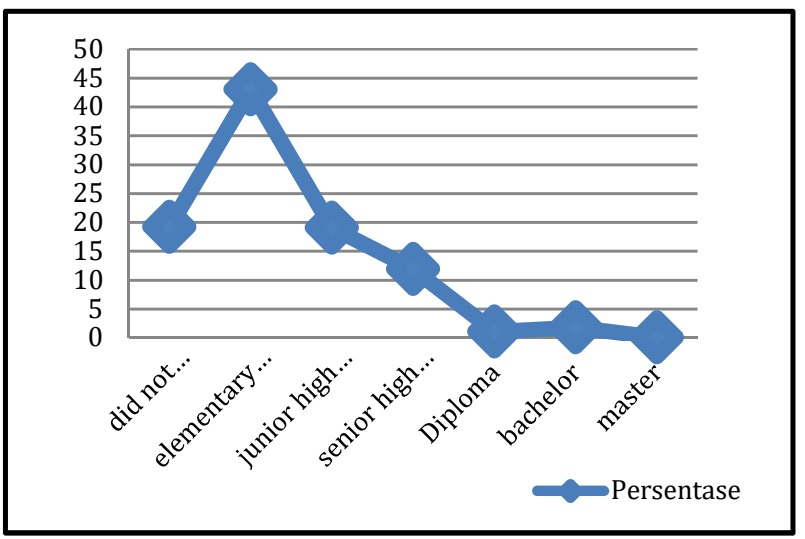

Figure 1. Population Education Level of Kabola Sub District, Broken Down by Village/ Sub-District 
Table 3. Livelihoods of Residents of Kabola Subdistrict, Alor Regency, 2017, Broken Down by Village

\begin{tabular}{lccrr}
\hline \hline Village / Sub-district & Government employees & Farmers / Fishermen & Laborers / Traders & Retired / Retired \\
\hline Alila Timur & 3 & 313 & 204 & 53 \\
Kabola & 154 & 1.027 & 2 & 1 \\
Kopidil & 15 & 230 & 2 & 10 \\
Lawahing & 11 & 433 & 2 & 1 \\
Pante Deere & 17 & 230 & 218 & 59
\end{tabular}

Source: Secretariat / District Government Section of Kabola District in the Kabola District Head's report (2018)

Table 3 shows that most of the residents of Kabola Subdistrict are farmers / fishermen and only a small proportion of them are civil servants, traders, and retirees.

The source of income for the residents of Kabola District consists of various sectors such as livestock farming, small industry, fisheries, the details can be seen in Figure 2.

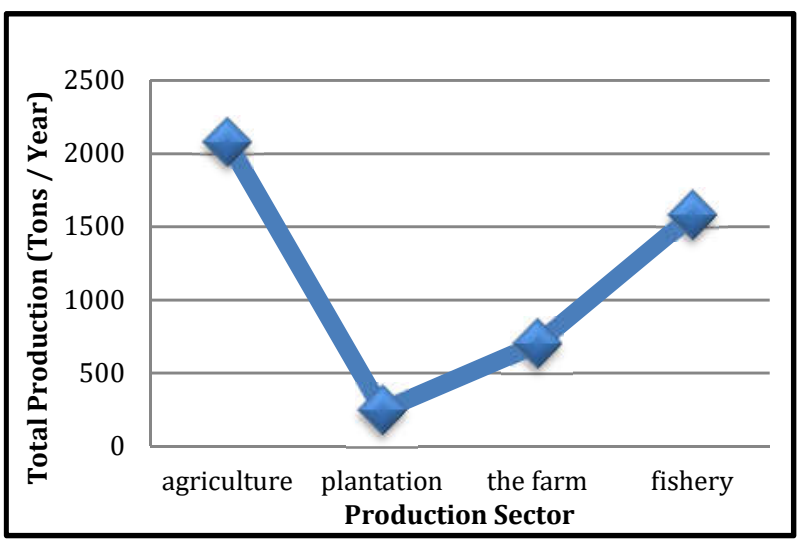

Figure 2. Community Income Sector Kabola District

Figure 2 shows that the largest production in Kabola District comes from the agricultural sector, with a total production of 2078,35 tons per year, while the smallest community income comes from the livestock sector with 246 tons per year.

\subsection{Main Research Findings in Relation to Problems Faced by Society}

In connection with the objectives and research questions as presented in the Introduction and by referring to the results and discussion as presented, this research has successfully obtained important findings regarding the problems faced by the Kabola ethnic group as follows:

1. The people of the Kabola ethnic group are still collecting wild food plants from forests, former gardens and riverbanks, even though they have cultivated various types of food crops;

2. The community of the Kabola ethnic group collects food plants during the rainy season and the dry season, but most food gathering activities are carried out at the end of the rainy season and during the dry season;

3. The people of the Kabola ethnic group collect food by using simple tools while leaving certain parts of the plant from which the food is collected;

4. The people of the Kabola ethnic group still pass on local knowledge about foodstuffs to the younger generation through stories, personal experiences and providing examples or direct practices about plants that can be used to meet food needs;

5. The Kabola ethnic group cultivates local food plants, but these cultivation efforts are only carried out individually and have not received support from the local government.

The five main findings above indicate that the Kabola ethnic group still pays attention to the principles of sustainability in utilizing various local plant species as food. However, because the efforts being made have not been institutionalized into a common awareness, for example in the form of groups, and have not received support from the local government, the sustainability of local food plants among the Kabola ethnic group is a threatened sustainability. According to Sikdar (2003), sustainability consists of three pillars, namely ecological pillars, economic pillars, and socio-cultural pillars and according to Bringesu (2002) and Fauzi (2004), sustainability contains two dimensions, namely the dimension of time and the dimension of interaction.

The economic pillar emphasizes on stable economic growth by increasing people's ability to increase economic value, increasing the efficiency of public services and forming institutions that hone people's ability to use natural resources and energy efficiently and efficiently. According to Rivai \& Anugrah (2016), economic sustainability means that an activity or business that is carried out must produce economic growth by maintaining, utilizing and investing in natural resources efficiently.

The social pillar emphasizes efforts to ensure social justice in equitable distribution of development results including agricultural products and community social services. According to Clift (2003), services for fulfilling needs and equitable fulfillment of human needs from various levels are a manifestation of social sustainability. Social sustainability must be a broad-based effort that helps ensure a fair, safe, adequate and stable food flow for people (Tilman et al. 2002). According to Harris et al (2001), McKezie (2004), Litting \& Grießler (2005), social sustainability includes equity in the distribution and opportunities for the formation of satisfying social services, including education and health, gender equality, political accountability and participation. The ecology pillar emphasizes the management, utilization and maintenance of natural resources and the environment wisely and sustainably. According to Jaya (2004) and Rivai \& Anugrah (2016), ecologically sustainable means that every activity must be able to maintain ecosystem integrity, maintain 
environmental carrying capacity and conserve natural resources including biodiversity.

Sustainability has two dimensions, namely the time dimension and the interaction dimension. The time dimension emphasizes what is happening now and what will happen in the future. According to Suarna (2018), the use of resources to meet current needs is still ongoing but does not sacrifice or reduce the needs of future generations. Continuity is very dependent on what is currently being done (Vasylieva et al. 2019). The interaction dimension emphasizes the interaction between people in realizing economic, social and ecological systems. According to Sudrajat (2018), community interaction individually and in groups plays a very important role in realizing sustainability. The interaction dimension also shows how the relationship affects each other that cannot be separated between the economic pillars, social pillars and ecological pillars (Muscalu et al., 2016).

\subsection{Research Synthesis}

Based on the research conducted by the author, it shows that the Kabola ethnic group still uses local plants as local food ingredients. Local food plants collected in gardens, former gardens, forests and riverbanks show that the Kabola ethnic group still depends on nature and has close or direct contact with nature. People who have direct contact with forests and gardens have a lot of knowledge about local food so they have a closeness and dependence on nature (Mengistu and Hager 2009). However, the sustainability of the use of foodstuffs by the Kabola ethnic group is threatened because there is no effort carried out by the community in groups as well as support from the government. To reduce this threat to sustainability, the community needs assistance from the government to enable them to receive the information needed to maintain sustainability. The government plays an important role in the maintenance, management, preservation and sustainability of wild food plants in their natural habitats and cultivated ones (Lulekal et al. 2011) because of the government's role in providing assistance and supervision (Barkatullah \& Abdullah 2016), especially transmitting new technology to increase human capacity. and institutional farmers through extension (Veerabhadraiah 2012).

Kabola ethnic group community processing local food by burning, boiling and mixing with other ingredients shows that the Kabola ethnic community has traditionally been able to maintain the sustainable use of food ingredients. However, on the other hand, the community still views that local food is food that has no price, has no selling value, is not nutritious and is an alternative food that is only used when experiencing food crisis, resulting in less than optimal attention to the sustainability of local food. The use of local food ingredients only as complementary food causes local plants that are useful as foodstuffs to receive less attention in efforts to strengthen community food security (Martianto et al. 2009a), because community groups who do not consume 48 modern food are still categorized as not having enough food (Sutanto). , 2002). In fact, if local food is used sustainably and managed to become modern foodstuffs, it will not only increase community food security but also provide high economic value as a source of income (Pieroni et al. 2005). The continued use of local food among the Kabola ethnic group is becoming increasingly threatened due to the threat of superior varieties of plants, monoculture cropping patterns, invasive plant species, low economic value, shifting people's understanding and views, and government assistance. Each of these threats is related to one another in shifting the existence of local food plants, both in relation to the cultivation of local food plants and in the use of wild food plants. The introduction of high-yielding varieties is a threat to the sustainability of food plants, as conveyed by one of the speakers named Abdi that:

"The corn we are planting right now is assistance from the government, we have lost the original corn, we have also lost ordinary yellow corn, and the local white corn is also about to disappear".

This statement means that the entry of superior varieties of yellow maize assisted by the government has resulted in the Kabola ethnic group that cultivates local yellow maize and local white maize to become less and less because the superior varieties of maize assisted by the government produce higher production compared to local maize production. According to Swaminathan (2016), the introduction of superior varietal food plants is the most threatening factor for the sustainability of local food plants because superior varieties are cultivated in monoculture. Monoculture cropping patterns have reduced the attention to the presence of various local food plant species so that they are threatened with loss. Monoculture cropping patterns are also cropping patterns that do not support ecosystem services, thus potentially threatening the long-term social and economic well-being of small farmers (Dickinson 1972).

The continued use of local food among the Kabola ethnic group is also becoming increasingly threatened due to the inclusion of invasive plant species, as stated by Yula in an interview that:

"... lantoro with the gamal has entered, so we give dead plants that we usually eat .... Kinds of lantana, low-ground, lala, lemeeng also give dead wild plants to what we usually grow, lantoro with the gamal is what evil, there may be a mixture".

This statement shows that certain groups in the Kabola ethnic group view the species of lamtoro (Leucaena leucocephala (Lamk.) De Wit) and gamal (Gliricidia sepium (Jacq.) Kunth ex Walp.) Which were introduced to reduce erosion and fertilize soil and lantana plants. (Lantana camara L.), kirinyu (Chromolaena odorata (L.) RM King \& H. Rob), malela (Brachiaria mutica Stapf), and wild growing grass (Eleusine indica (L.) Gaertn) can lead to the extinction of several species. wild food plants. According to Anwar et al. (2011), lamtoro and gamal plants produce allelopathic compounds that can inhibit the 
growth of other plant species. Allelopathy is mediated by secondary metabolites and released through leaching, root exudation, volatilization, and residue decomposition into the environment so that it can affect plant growth and development in natural and agro-ecosystem environments (Cheema et al., 2013). The introduction of invasive plant species has been shown to result in the loss of several native plant species (Akinnifesi et al. 2010).

Low economic value is a threat to the sustainability of food crops as stated by Abia that:

"... the government only brings corn seeds, but people never buy. We have existing corn products, so we have corn at no market price." .... so we got no corn prices."

This statement shows that the economic value and distribution of agricultural products to wholesalers is a problem for the Kabola ethnic group, so that the production of local food plants such as corn, rice, various beans, and various vegetables is still consumed by themselves. Low agricultural production prices can hinder farmers from developing agricultural plants (Kusumo et al., 2018). According to Susilowati (2016), the low economic value of agricultural products results in people not being interested in developing agriculture. Market price is a factor that motivates farmers to maintain and care for agricultural plants intensively (Yudiarini, 2017). According to Widiastuti \& Harisudin (2013), the distribution of the harvest to the buyers is a supporting factor in increasing people's income. Eaton (2008) states that efforts to increase the farmer's economy through the marketing of harvest channels greatly affect sustainable agricultural productivity. This statement also shows that there is no government policy regarding the value of local community agricultural production. The same statement also implies that low agricultural production prices can lead to a shift in people's livelihoods from the agricultural sector to leaving the agricultural sector as stated by Allen (2010). Mishra et al. (2009) stated that low income in the agricultural sector encourages community members to shift their livelihoods to sectors outside the agricultural sector.

Another threat that is also faced by the Kabola ethnic group in maintaining the sustainability of local food is the community's view of local food that local food is an old food, not prestigious, and with low nutritional content, as stated by Okla'a in an interview that:

“.... the children don't want to eat we have more food, dorang said wild plants and cultivated plants include cassava, corn, banana, kow, there are food items that are not important, no nutrition, left behind, it is not good to be a dorang don't want to eat it."

This statement can be interpreted that some of the Kabola ethnic group community considers that local food is a past food ingredient, not nutritious and not important for consumption. According to Luthfi \& Salung (2015), the younger generation always believes that local food from local farmers' businesses is past food that is not promising. Martianto et al (2009b) stated that there are local people who consider processed local food products as food products that are not prestigious and out of date.

Threat that is no less important is the existence of various threats that are no less important is the existence of various local food plants as conveyed by Yapen that:

"... the more government assistance, so we are pleased, we children forget that we have local food and are unable to keep us from real food".

What is meant in this statement is government assistance in the form of rice and direct cash assistance which causes people to feel secure for their food needs and become increasingly dependent on rice, thus ignoring the existence and sustainability of local food plant species. Silva et al (2016) stated that direct cash assistance from the government to local communities encourages people to buy more processed products from outside instead of consuming food from self-cultivated plants.

\subsection{Implications of Research Results}

The findings of this study that the Kabola ethnic group faces the sustainability of being threatened in the use of local food plants raises a number of implications that need the attention of all parties. Among other things, the implications that need immediate attention are threats to the existence and sustainability of local food plant species. The threat of loss of local food plant species can occur in the absence of a program government to protect local plant genetic resources (Reijntjes et al., 1999; Suharjo 2019). This threat can be increased due to changes in habits of consuming modern food (Teklehaymano \& Giday 2010; Zuraida \& Supriati 2001) changes in livelihoods to leave agriculture (Allen 2010; Dickinson 1972; Mishra et al., 2009), and there has been no real effort to promote diversification of food consumption (Irawan \& Sutrisna 2011).

The next implication is for efforts to strengthen the food security of the community, especially the Kabola ethnic group. As described in the previous subchapter, the Kabola ethnic group has maintained their food security so far by utilizing various species of local food plants. However, the sustainable use of local food plant species to maintain food security faces various threats that require strengthening to reduce the risk of facing food insecurity and reduce dependence on food security. food supply from outside. To strengthen people's food security, the government needs to provide policy support and commitment to the application of technology to increase food production and processing (Budhi, 2010) and provide support for efforts to increase food security through strengthening household food security in meeting their food needs (Purwaningsih, 2008). To achieve the goal of strengthening household food security, the government needs to provide agricultural extension services that include the development of local food plant species to strengthen food security (Veerabhadraiah 2012). 
Another implication that also needs attention is the efforts to develop dry land agriculture to alleviate people from poverty. The soil physical environment, topography, and climate in Kabola sub-district are suitable environmental conditions for the development of dry land agriculture. Sustainable development of dry land agriculture is only possible if done by using plant species that have adapted to local environmental conditions. On the other hand, as has been described in the same sub-chapter, the socioeconomic environment of the Kabola ethnic group is still characterized by large household accounts and low income so that the Kabola ethnic group community still under the pressure of poverty. According to Susanti et al., (2015) and Prasetyaningtyas \& Nindya, (2018), households with large dependents will focus on efforts to meet household food needs. Coupled with community access to production technology which is still very limited, the threatened sustainability faced by the Kabola ethnic group can have less prospective implications for efforts to develop dry land agriculture to alleviate people from poverty.

\section{Conclusion}

Taking into account the research objectives and based on the results and discussion that has been done above, it is concluded that the Kabola ethnic group has sufficient understanding and knowledge of the sustainability of local food plants, but cannot fully sustain local food plant species due to the threat of the introduction of superior varieties, monoculture cropping, introduction of invasive species, economic value and a shift in people's understanding.

\section{REFERENCES}

Akinnifesi, Festus Kehinde, Gudeta W. Sileshi, Oluyede C. Ajayi, Adetutu I. Akinnifesi, Emanoel G. de Moura, Jairo F. P. Linhares, and Ivanilde Rodrigues. 2010. Biodiversity of the Urban Homegardens of São Luís City, Northeastern Brazil. Urban Ecosystems Vol. 13 No. 1. Pages 129-46.

Albuquerque, Ulysses Paulino. 2017. Ethnobotany for Beginners. New York, NY: Springer Science Business Media.

Allen, P. 2010. Realizing Justice in Local Food Systems. Cambridge Journal of Regions, Economy and Society Vol. 3 No. 2. Pages 295-308.

Anwar, Risvan, Ikhsan Hasibuan, dan Pusriani Hayati. 2011. Uji Allelopati Potensial Terhadap Perkecambahan Gulma Echinochloa cruss-galli (L.) Beauv. Jurnal Agroqua Vol. 9 No. 2. Hal. 6.

Badan Pusat Statistik Kabupaten Alor. 2018. Badan Pusat Statistik Kabupaten Alor (Kecamatan Kabola Dalam Angka).

Barkatullah, Abdul Halim, dan Dadang Abdullah. 2016. Tanggung Jawab Pemerintah Dalam Menjaga Kualitas Lingkungan Di Wilayah Penambangan Intan Tradisional Cempaka. Al'Adl Vol. VIII No. 3. Hal. 22.

Berkes, Fikret, Johan Colding, and Carl Folke. 2000. Rediscovery of Traditional Ecological Knowledge as Adaptive Management. Ecological Applications Is
Currently Published by Ecological Society of America. Vol. 10 No. 5. Pages 13.

Berkes, Fikret, and C. folke. 1994. Linking Social and Ecological Systems for Resilience and Sustainability. Kfuwer AcademiC Publishers, Vol. 23.

Berkes, Fikret, Carl Folke, and Madhav Gadgil. 1995. Tradisional Ecological Knowledge, Biodiversity, Resilience And Sustainability. Kfuwer AcademiC Publishers, Vol. 2.

Bringezu, Stefan. 2002. Towards Sustainable Resource Management in the European Union. 121. Wuppertal Papers.

Charnley, Susan, A. Paige Fischer, and Eric T. Jones. 2007. Integrating Traditional and Local Ecological Knowledge into Forest Biodiversity Conservation in the Pacific Northwest. Forest Ecology and Management Vol. 246 No. 1. Pages 14-28.

Cheema, Zahid A., Muhammad Farooq, and Abdul Wahid, eds. 2013. Allelopathy, Current Trends and Future Apllications. Berlin, Heidelberg: Springer Berlin Heidelberg.

Clift, Roland. 2003. Metrics for Supply Chain Sustainability." Clean Technologies and Environmental Policy Vol. 5 No. 3-4. Pages 240-47.

Creswell. 2014. Research Design: Qualitative, Quantitative, and Mixed Methods Approaches. Thousand Oaks, London. New Delhi: Sage Publications.

Creswell, John W. 2007. An Introduction to Mixed Methods Research. University of Nebraska-Lincoln, Vol. 43.

Dickinson, J. C. 1972. Alternatives to Monoculture In The Humid Tropics Of Latin America. The Professional Geographer Vol. 24 No. 3. Pages 217-22.

Eaton, Emily. 2008. From Feeding the Locals to Selling the Locale: Adapting Local Sustainable Food Projects in Niagara to Neocommunitarianism and Neoliberalism. Geoforum Vol. 39 No. 2. Pages 994-1006.

Elfitri, E. Kurnia, M Pawit Yusup, and Wina Erwina. 2017. Komunikasi Budaya Masyarakat Pandai Sikekdalam Melakukan Transformasi Pengetahuan Lokal. Jurnal Kajian Informas i\& Perpustakaan Vol. 5 No. 2. Hal. 141-54.

Fadhilah, A. 2013. Kearifan Lokal dalam Membentuk Daya Pangan Lokal Komunitas Molamahu Pulubala Gorontalo. Al-Turāś Vol. XIX No. 1. Hal. 16.

Fauzi, Akhmad. 2004. Ekonomi Sumber Daya Alam dan Lingkungan: Teori dan Aplikasi. Gramedia Pustaka Utama.

Fauzi, Rahma Widyastuti, Heru Sudrajad, Fredolina Mau, dan M. Mefi Talan. 2017. Eksplorasi Pengetahuan Lokal Etnomedisin dan Tumbuhan Obat Berbasis Komunitas di Indonesia Provinsi Nusa Tenggara Timur. Lembaga Penerbitan Badan Penelitian dan Pengembangan Kesehatan Kementerian Kesehatan RI.

Francesconi, Wendy, B Vincent, B. C Genowefa, W Simon, C Sandra, V Martha, Q Marcela, and A. Torres-Vitolas Carlos. 2018. Hunters and Hunting across Indigenous and Colonist Communities at the Forest-Agriculture Interface: An Ethnozoological Study from the Peruvian Amazon. Journal of Ethnobiology and Ethnomedicine Vol. 14 No. 1. Page 54.

Frankenberger, Tim, Mark Langworthy, Tom Spangler, and Suzanne Nelson. 2012. Enhancing Resilience to Food Security Shocks. Tango International, Inc., Vol. 59.

Hapsari, Windy. 2013. Tambelo (Bactronophorus Thoracites) Jurnal Papua Vol. V No. 2. Page 11.

Harris, T. A. Wise, K. P. Gallagher, and N. R. Goodwin,. 2001. A Survey of Sustainable Development: Social and 
Economic Dimensions. Environmental Practice, Vol. 3 No. 4. Pages 263-64.

Inglis, Julian, International Program on Traditional Ecological Knowledge, International Development Research Centre (Canada), and International Association for the Study of Common Property, eds. 1993. Traditional Ecological Knowledge: Concepts and Cases. Ottawa, Ont., Canada: International Program on Traditional Ecological Knowledge : International Development Research Centre.

Irawan, Bambang, and Nana Sutrisna. 2011. Prospect of Sorghum Development in West Java to Support Food Diversification. Forum Penelitian Agro Ekonomi, Vol. 29 No. 2. Pages 99-113.

Jaya, Askar. 2004. Sustainable Development. Institut Pertanian Bogor, Vol. 11.

Kusumo, K. R. Andriani, Elly Rasmikayati, dan Gema Wibawa Mukti. 2018. Perilaku Petani Dalam Usahatani Mangga Di Kabupaten Cirebon. Mimbar Agribisnis: Jurnal Pemikiran Masyarakat Ilmiah Berwawasan Agribisnis Vol. 4 No. 2. Hal. 197.

Littig, Beate, and Erich Grießler. 2005. Social Sustainability. A Catchword between Political Pragmatism and Social Theory. International Journal for Sustainable Development, Vol. 8 No. 1/2. Pages 65-79.

Lulekal, Ermias, Zemede Asfaw, Ensermu Kelbessa, and Patrick Van Damme. 2011. Wild Edible Plants in Ethiopia: A Review on Their Potential to Combat Food Insecurity. Afrika Focus Vol. 24 No. 2.

Luthfi, Ahmad Nashih, and Surya Saluang. 2015. Masa Depan Anak Muda Pertanian Di Tengah Liberalisasi Pertanahan. Bhumi: Jurnal Agraria dan Pertanahan Vol. 1 No. 1.

Martianto, Drajat, Dodik Briawan, Mewa Ariani, and Nita Yulianis. 2009a. Percepatan Diversifikasi Konsumsi Pangan Berbasis Pangan Lokal: Perspektif Pejabat Daerah Dan Strategi Pencapaiannya. Jurnal Gizi dan Pangan Vol. 4 No. 3. Hal. 123.

Martianto, Drajat, Dodik Briawan, Mewa Ariani, and Nita Yulianis. 2009b. Percepatan Diversifikasi Konsumsi Pangan Berbasis Pangan Lokal: Perspektif Pejabat Daerah Dan Strategi Pencapaiannya. Jurnal Gizi dan Pangan Vol. 4 No. 3. Hal. 123.

McKenzie, Stephen. 2004. Social Sustainability: Towards Some Definitions. Hawke Research Institute University of South Australia Magill, South Australia Vol. 1 No. 27. Page 31.

Mengistu, Fentahun, and Herbert Hager. 2009. Wild Edible Fruit Species Cultural Domain, Informant Species Competence and Preference in Three Districts of Amhara Region, Ethiopia. Ethnobotany Research and Applications Vol. 6. Page 487.

Menzies, Charles R., ed. 2006. Traditional Ecological Knowledge and Natural Resource Management. Lincoln: University of Nebraska Press.

Mishra, Ashok, Hisham El-Osta, and Jeffrey M. Gillespie. 2009. Effect of Agricultural Policy on Regional Income Inequality among Farm Households." Journal of Policy Modeling Vol. 31 No. 3. Pages 325-40.

Muscalu, Emanoil, Mihai Neag, and E. Elisabeta Halmaghi. 2016. The Ecological Dimension of Sustainable Development. Scientific Research And Education In The Air Force-Afases. Pages 1-6.

Nunes, M. Guerra Natan, N Ernane, Arévalo-Marín Edna, A. B. Alves Carlos, T. do Nascimento Viviany, D. da Cruz Denise, et al. 2018. Local Botanical Knowledge of Native Food Plants in the Semiarid Region of Brazil.
Journal of Ethnobiology and Ethnomedicine Vol. 14 No. 1. Pages 49 .

Peraturan Mentri Pertanian Nomor : 47/Permentan/OT.140/10/2006. 2006. Tentang Pedoman Umum Budidaya Pertanian Pada Lahan Pegunungan.

Perda Kab Alor Nomor 15 Tahun. 2005. Peraturan Daeraha Kabupaten Alor Nomor: 15 Tahun 2005 Tentang Pembentukan Kecamatan di Kabupaten Alor." Pemerintah Daerah Kabupaten Alor.

Pieroni, Andrea, Sabine Nebel, Rocco Franco Santoro, and Michael Heinrich. 2005. Food for Two Seasons: Culinary Uses of Non-Cultivated Local Vegetables and Mushrooms in a South Italian Village. International Journal of Food Sciences and Nutrition Vol. 56 No. 4. Pages 245-72.

Prasetyaningtyas, Dewi, and Triska Susila Nindya. 2018. Hubungan Antara Ketersediaan Pangan dengan Keragaman Pangan Rumah Tangga Buruh Tani. Media Gizi Indonesia Vol. 12 No. 2. Hal. 149.

Purwaningsih, Yunastiti. 2008. Ketahanan Pangan: Situasi, Permasalahan, Kebijakan, Dan Pemberdayaan Masyarakat. Jurnal Ekonomi Pembangunan: Kajian Masalah Ekonomi dan Pembangunan Vol. 9 No. 1. Hal. 1.

Reijntjes, Coen, Bertus Haverkort, and Ann Waters-Bayer. 1999. Pertanian Masa Depan: Pengantar untuk Pertanian Berkelanjutan dengan Input Luar Rendah. Kanisius.

Rivai, Rudy Sunarja, and Iwan Setiajie Anugrah. 2016. Konsep dan Implementasi Pembangunan Pertanian Berkelanjutan di Indonesia. Forum Penelitian Agro Ekonomi Vol. 29 No. 1. Hal. 13.

Sekretariat/Sie Pem Kecamatan Kabola dalam laporan camat KabolA. 2018. Laporan Camat Kabola Pada Rapat Koordinasi Pamong Praja Tingkat Kabupaten Alor.

Sikdar, Subhas K. 2003. Sustainable Development and Sustainability Metrics. Aiche Journal Vol. 49 No. 8. Pages 1928-32.

Silva, J. D. Rodrigo, E. P. E. Maria Garavello, B. Gabriela Nardoto, A. Edmar Mazzi, and Luis Martinelli. 2016. Case Study Factors Influencing the Food Transition in Riverine Communities in the Brazilian Amazon. Springer Science+Business Media Dordrecht 2016, March. Pages 1-16.

Suarna, I Wayan. 2018. Bali Dalam Tarikan Pembangunan Berkelanjutan. Jurnal Bappeda Litbang Vol. 1 No. 3. Hal. 1-8.

Subardja, Djadja, Sofyan Ritung, Markus, and Rudy Subandiono. 2014. Petunjuk-Teknis-KlasifikasiTanah-Nasional.-2014.Pdf. Balai Besar Litbang Sumberdaya Lahan Pertanian Badan Penelitian Dan Pengembangan Pertanian, Edisi-1.

Sudrajat, A. S. Edy. 2018. Pilar Pembangunan Berkelanjutan: Kajian Pengelolaan Sumber Daya Alam Dan Lingkungan Kampung Batik Rejomulyo Semarang Timur. Riptek Vol. 12 No. 1. Hal. 6.

Suharjo. 2019. Sistem Pertanian Berkelanjutan: Model Pengelolaan Tanaman. Media Sahabat Cendekia.

Susanti, Elly, T Fauzi, and Taufiqurrahman. 2015. Analisis Ketahanan Pangan Rumah Tangga Petani Di Desa Ulee Lhat Kecamatan Montasik Kabupaten Aceh Besar. Jurnal Bisnis Tani Vol. 1 No. 1. Hal. 11-23.

Susilowati, Sri Hery. 2016. Fenomena Penuaan Petani dan Berkurangnya Tenaga Kerja Muda serta Implikasinya bagi Kebijakan Pembangunan Pertanian. Forum penelitian Agro Ekonomi Vol. 34 No. 1. Hal. 35. 
Sutanto, Rachman. 2002. Pertanian organik: menuju pertanian alternatif dan berkelanjutan. Kanisius.

Swaminathan, Divya Rajeswari. 2016. Agricultural Transformation and Indigenous Communities : A Case Study of the Soliga Communities in the Montane Forests, Southern India, Vol. 99.

Teklehaymano, Tilahun, and Mirutse Giday. 2010. Ethnobotanical Study of Wild Edible Plants of Kara and Kwego Semi-Pastoralist People in Lower Omo River Valley, Debub Omo Zone, SNNPR, Ethiopia. Journal of Ethnobiology and Ethnomedicine Vol. 6 No. 23. Pages 1-8.

Tilman, David, Kenneth G. Cassman, Pamela A. Matson, Rosamond Naylor, and Stephen Polasky. 2002. Agricultural Sustainability and Intensive Production Practices. Nature Vol. 418 No. 6898. Pages 671-77.

Toledo, Álvaro, and Barbara Burlingame. 2006. Biodiversity and Nutrition: A Common Path toward Global Food Security and Sustainable Development. Journal of Food Composition and Analysis Vol. 19. Pages 477-83.

Torre-Cuadro, L.L.D.M, and A.G Islabe. 2003. Traditional Ecological Knowledge and Use of Vegetation in Southeastern Mexico: A Case Study from Solferino, Quintana Roo. Kluwer Academic Publishers. Printed in the Netherlands. Vol. 2 No. 22.
Vasylieva, Lyulyov, Bilan, and Streimikiene. 2019. Sustainable Economic Development and Greenhouse Gas Emissions: The Dynamic Impact of Renewable Energy Consumption, GDP, and Corruption. Energies Vol. 12 No. 17. Page 3289.

Veerabhadraiah, V. 2012. Emerging Agricultural Extension Models." Indian Research Journal of Extension Education Special Issue Vol. I No. 4.

Widiastuti, Nur, and Mohd Harisudin. 2013. Saluran Dan Marijin Pemasaran Jagung Di Kabupaten Grobokan. SEPA Vol. 9 No. 2. Page 10.

Williams, C.G. 1996. Adaptation and Natural Selection: A Critique of Some Current Evolutionary Thought. Princeton Science Library. Princeton, NJ: Princeton Univ. Press.

Yudiarini, Nyoman. 2017. Perubaha Pertanian Subsisten Tradisional Ke Pertanian Komersial. dwijenAGRO Vol. 2 No. 1. Hal. 8.

Zuraida, Nani, and Yati Supriati. 2001. Usahatani Ubi Jalar Sebagai Bahan Pangan Alternatif Dan Diversifikasi Sumber Karbohidrat. Buletin AgroBio Vol. 4 No. 1. Hal. 13-23. 